\title{
The CFD Analysis of the Combustion Chamber in Common Rail Engines
}

\author{
Karol Tucki ${ }^{1, *}$, Anna Bączyk $^{2}$, Bartłomiej Rek $^{1}$, and Izabela Wielewska ${ }^{3}$ \\ ${ }^{1}$ Warsaw University of Life Sciences, Department of Organization and Production Engineering, Nowoursynowska Street 164, 02-787 \\ Warsaw, Poland \\ ${ }^{2}$ Warsaw University of Life Sciences, Department of Hydraulic Engineering, Nowoursynowska Street 159, 02-776 Warsaw, Poland \\ ${ }^{3}$ UTP University of Science and Technology in Bydgoszcz, Department of Agronomy, Fordońska Street 430, 85-790 Bydgoszcz, \\ Poland
}

\begin{abstract}
This paper reports on the development of the geometrical model of the combustion chamber. The results obtained from test were applied to numerical simulations - performed on the Farymann 18WM engine. The analysis was carried out in ANSYS Fluent environment using the finite volume element method. Based on the results, it can be stated that: (1) differences in test and simulation results result from: grid limitations, accuracy of the calculation models, simplifications and limitations of the models, (2) numerical simulations are helpful in determining the parameters of test objects without the need for employing a test set-up, finally, (3) unrestrained adjustment of simulation parameters enables modification of technical parameters of devices to assess their impact on the particular model.
\end{abstract}

\section{Introduction}

The progressive development of technology forces the need to find new and more efficient design methods. Modern engines and power units are extremely complex mechanical and electrical systems. The application of the direct injection requires designers to apply small ranges of production tolerance in order to achieve the intended goal. The working of systems is becoming increasingly dependent on smaller and smaller elements. Engine design teams must balance between operating costs and performance. As a result, there is a significant increase in the quality of fuels used in engines [1-4]. Reduced fuel consumption and the striving for the highest environmental standards contribute to the search for alternative fuels of origins other than oil [5-16]. One of the alternatives is rapeseed oil. The advantages of vegetable oil fuels include the method of production and the low level of carbon dioxide emissions. Diesel engines powered by rapeseed oil require the use of extremely precise tools, both in design and manufacture. One of such tools is the Computational Fluid Dynamics (CFD) software. It uses the finite element and finite volume methods [17-22]. If applied skilfully the software enables developing efficient systems with high precision and in short time. The high accuracy of calculations leads to significant design cost reduction [23, 24].

The purpose of this paper was to: (1) develop a fuel injection simulation for the Farymann $18 \mathrm{~W}$ diesel combustion chamber based on laboratory data, (2) compare the calculation method with the experimental method in the context of diesel injector design, (3) determine the basic parameters of the injection phenomenon and implement them in the Fluent program, (4) verify the behaviour of the fuel flow under a different injection pressure based on experimental tests.

\section{Materials and methods}

For the purpose of this paper, a three-dimensional geometric model of the combustion chamber, together with a computational grid were developed (Fig. 1).

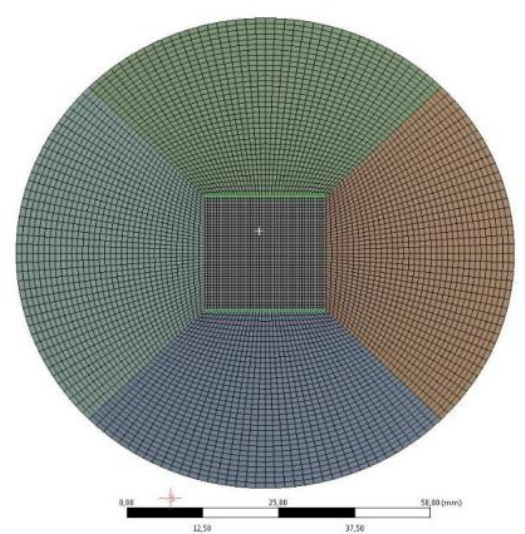

Fig. 1. Projection of geometrical model with computational grid.

Test parameters obtained from experimental tests were implemented in numerical simulations performed on the Farymann 18WM engine. The objective of such tests was to adapt the diesel engine to the rapeseed oil power supply. Unfortunately, the application of this oil on a large scale is hindered by its high viscosity [25]. For this purpose, the direct fuel injection system, fed with the high

*Corresponding author: karol_tucki@sggw.pl 
pressure pump, was replaced with the Common Rail system [26-29].

The analysis was performed in the ANSYS Fluent [30] environment using the finite volume element method. The analysis consists of five simulation stages: (1) preprocessing, (2) mesh - generating the calculation grid for the previously developed model, (3) entering all data required for simulation, (4) starting calculations, (5) postprocessing - interpreting and displaying obtained results. The injection parameters are shown in Table 1.

Table 1. Parameters of the analysed fuel injection.

\begin{tabular}{|l|c|c|}
\hline X-Position & \multicolumn{2}{|c|}{ Azimuthal Stop Angle } \\
\hline Y-Position & $50.5 \mathrm{~mm}$ & X - Axis \\
\hline Z-Position & 0 & Y - Axis \\
\hline Diameter & $0.16 \mathrm{~mm}$ & Z - Axis \\
\hline Temperature & $350{ }^{\circ} \mathrm{K}$ & $\begin{array}{c}\text { Velocity } \\
\text { Magnitude }\end{array}$ \\
\hline Start time & $0 \mathrm{~s}$ & $\begin{array}{c}\text { Half Cone } \\
\text { Angle }\end{array}$ \\
\hline Stop Time & $0.001 \mathrm{~s}$ & Radius \\
\hline Azimuthal Start Angle & $0^{\circ}$ & $\begin{array}{c}\text { Total Flow } \\
\text { Rate }\end{array}$ \\
\hline
\end{tabular}

The injection velocity was calculated from the following formula (1)

$$
u_{r l}=\sqrt{\frac{2\left(p_{w}-p_{c l}\right)}{\rho_{p a l}}}
$$

where: $p w^{-}$is the injection pressure, $p c l-$ is the cylinder pressure, and $\rho p a l$ - is the fuel density

The values of the fuel injection velocity are shown in Table 2.

Table 2. Fuel injection velocity for $p c l=100000 \mathrm{~Pa}$ and $p c l=$ $150000 \mathrm{~Pa}$.

\begin{tabular}{|c|c|c|}
\hline \multirow{2}{*}{$\begin{array}{c}\text { injection pressure } \\
{[\mathrm{MPa}]}\end{array}$} & $\begin{array}{c}\text { pressure in the } \\
\text { chamber }= \\
100000[\mathrm{~Pa}]\end{array}$ & $\begin{array}{c}\text { pressure in the } \\
\text { chamber }= \\
1500000[\mathrm{~Pa}]\end{array}$ \\
\cline { 2 - 3 } & velocity [m/s] & velocity $[\mathrm{m} / \mathrm{s}]$ \\
\hline 60 & 378.78 & 374.33 \\
\hline 90 & 464.04 & 460.41 \\
\hline 120 & 535.90 & 532.76 \\
\hline 150 & 599.20 & 596.40 \\
\hline
\end{tabular}

The simulation structure was determined on SIMPLE with an indication of the connection with the volume fraction. The spatial discretisation of the kinetic energy mass, momentum turbulence, dispersion output rate and total energy was set to QUICK (Quadric Upstream Interpolation for Convective Kinematics) type. This option is selected when the model is set to Pressure-based and if the upper and lower bound can be specified. In the case of spatial discretisation of the gradient, the GreenGaus Cell Based option was used.

\section{Results}

Once all parameters and input data were entered, the calculation results for direct injection were generated. Eight analyses of fuel injection were performed. Four injection pressure values (60 MPa, $90 \mathrm{MPa}, 120 \mathrm{MPa}$ and
$150 \mathrm{MPa}$ ) were set for two different pressure values in the combustion chamber (0.1 $\mathrm{MPa}$ and $1.5 \mathrm{MPa})$. The results included: temperature $[\mathrm{K}]$, average injection velocity $\left[\mathrm{m} \cdot \mathrm{s}^{-1}\right]$ with its distribution in the stream, the velocity of individual drops $\left[\mathrm{m} \cdot \mathrm{s}^{-1}\right]$ and the distribution of drop diameters $[\mathrm{mm}]$ generated as a result of disintegration. The obtained results (Fig. 2) were compared with the results of experimental research [5].

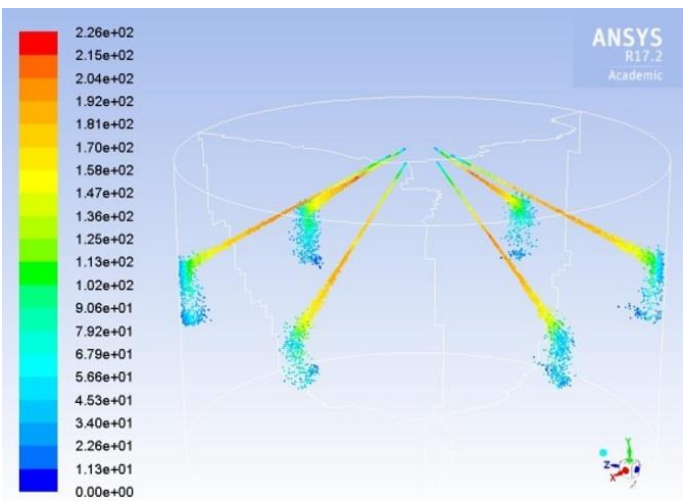

Fig. 2. Velocity distribution in the 3D model of combustion chamber.

The streak method in the study of fuel injection process uses the differences in brightness of the light passing through the stream as a result of the change in the refractive index. This coefficient depends on the density of the medium. The streak method uses changes in brightness of lighting to assess the test area.

The laboratory tests were carried out with a streak camera with a laser light source recording at a pulse frequency of $10,000 \mathrm{~Hz}$ and a drum camera. The change of the fuel stream image for different pressures is shown in Fig. 3.

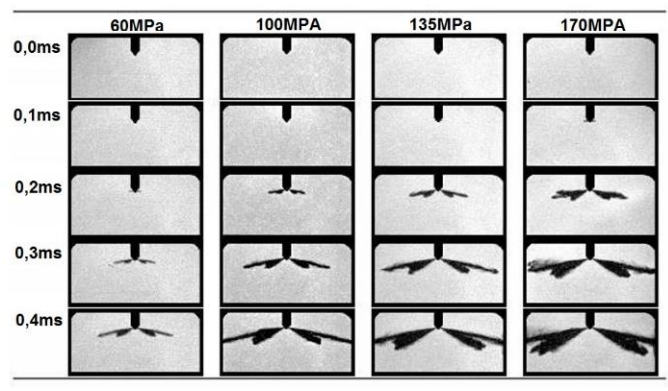

Fig. 3. View on fuel spray in the plane vertical to injector axle for different pressures $(60,100,135,170 \mathrm{MPa})$ [5].

At standard pressure occurring in conventional fuel systems, we observe the beginning of the outflow of fuel from the nozzle, the fuel stream at $170 \mathrm{MPa}$ reaches the chamber walls. A stream of fuel with a higher pressure is characterised not only by a higher rate of penetration, but also by greater spraying (increase in the volume of the stream). The increase in pressure also increases the homogeneity of the stream and decreases the drop size. Another method used in tests was the PIV System (Particle Image Velocimetry), which enables visualisation of the velocity field in the observed measuring space, in which the sprayed drops are irradiated with two short 
pulses of laser. The time of a single laser pulse is a few nanoseconds, while the time between pulses is a few microseconds. During the laboratory tests, images of the sprayed process were recorded for different times, counting from the beginning of the injection, which allowed to determine velocity change as a function of time. An example of the velocity field of the sprayed commercial fuel at the injection pressure $100 \mathrm{MPa}$ for the time $0.41 \mathrm{~ms}$ from the injection start is shown in Fig. 4.

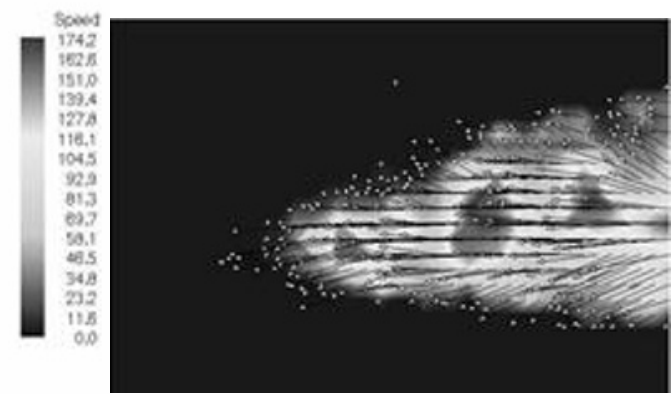

Fig. 4. Velocity field of the sprayed commercial fuel at the injection pressure $100 \mathrm{MPa}$ for the time $0.41 \mathrm{~ms}$ from the injection start.

An example of the velocity change for different pressures is shown in Fig. 5.

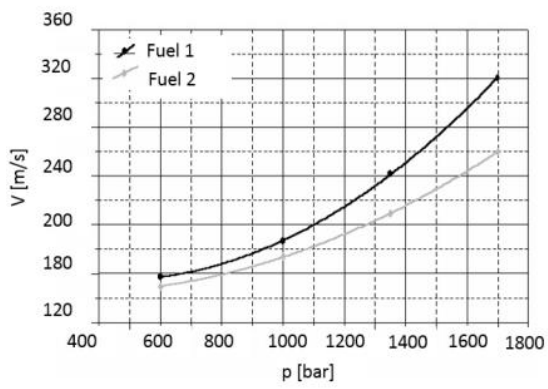

Fig. 5. Chart of fuel spray velocity change for different pressures (injection time $1.5 \mathrm{~ms}$ ). Fuel 1 - viscosity of $4.7 \mathrm{~mm}^{2} / \mathrm{s}$, fuel 2 viscosity of $1.7 \mathrm{~mm}^{2} / \mathrm{s}$ [5].

In new fuel supply systems (Common Rail injectors), the increase in pressure significantly changes the injection characteristics, resulting in increased range of the spray and increase in the uniformity and velocity, as well as a change in the spraying angle.

The increase in injection pressure from 60 to $170 \mathrm{MPa}$ caused that after $0.3 \mathrm{~ms}$ from the beginning of injection the difference in the jet path was $0.05 \mathrm{~m}(5 \mathrm{~cm})$ for fuel with viscosity of $4.7 \mathrm{~mm}^{2} / \mathrm{s}$ and $0.03 \mathrm{~m}(3 \mathrm{~cm})$ for fuel with a viscosity of $1.7 \mathrm{~mm}^{2} / \mathrm{s}$.

When fuel viscosity is reduced, a less ordered velocity distribution is observed. In addition, an increase in the volume of the spray space was noted.

The increase in injection pressure from 60 to $170 \mathrm{MPa}$ caused that after $0.3 \mathrm{~ms}$ from the beginning of injection the difference in the jet path was $0.05 \mathrm{~m}(5 \mathrm{~cm})$ for fuel with viscosity of $4.7 \mathrm{~mm}^{2} / \mathrm{s}$ and $0.03 \mathrm{~m}(3 \mathrm{~cm})$ for fuel with a viscosity of $1.7 \mathrm{~mm}^{2} / \mathrm{s}$. The increase in viscosity not only causes an increase in the range of the stream, but also reduction in fuel atomisation and an increase in the velocity of the stream face from 260 to $320 \mathrm{~m} / \mathrm{s}$ (at a pressure of $170 \mathrm{MPa}$ ).Such large differences both in terms of the velocity of the stream, as well as the volume of spray and the range of the stream affect the process of creating the fuel-air mixture.

In the next step, a CFD fuel flow analysis was performed.

As emphasised above for the sake of visualisation of the stream distribution, the viscosity of the fuel is crucial.

Unfortunately, ideal determination of the viscosity of fuels used in experimental studies was not possible, and therefore we could observe clear differences in the performance of experimental studies and CFD analyses. These differences were eliminated by the use of the appropriate coefficients of viscosity during CFD analyses by trial and error.

The results of individual fuel injections were presented for the $0.1 \mathrm{MPa}$ pressure value in the combustion chamber.
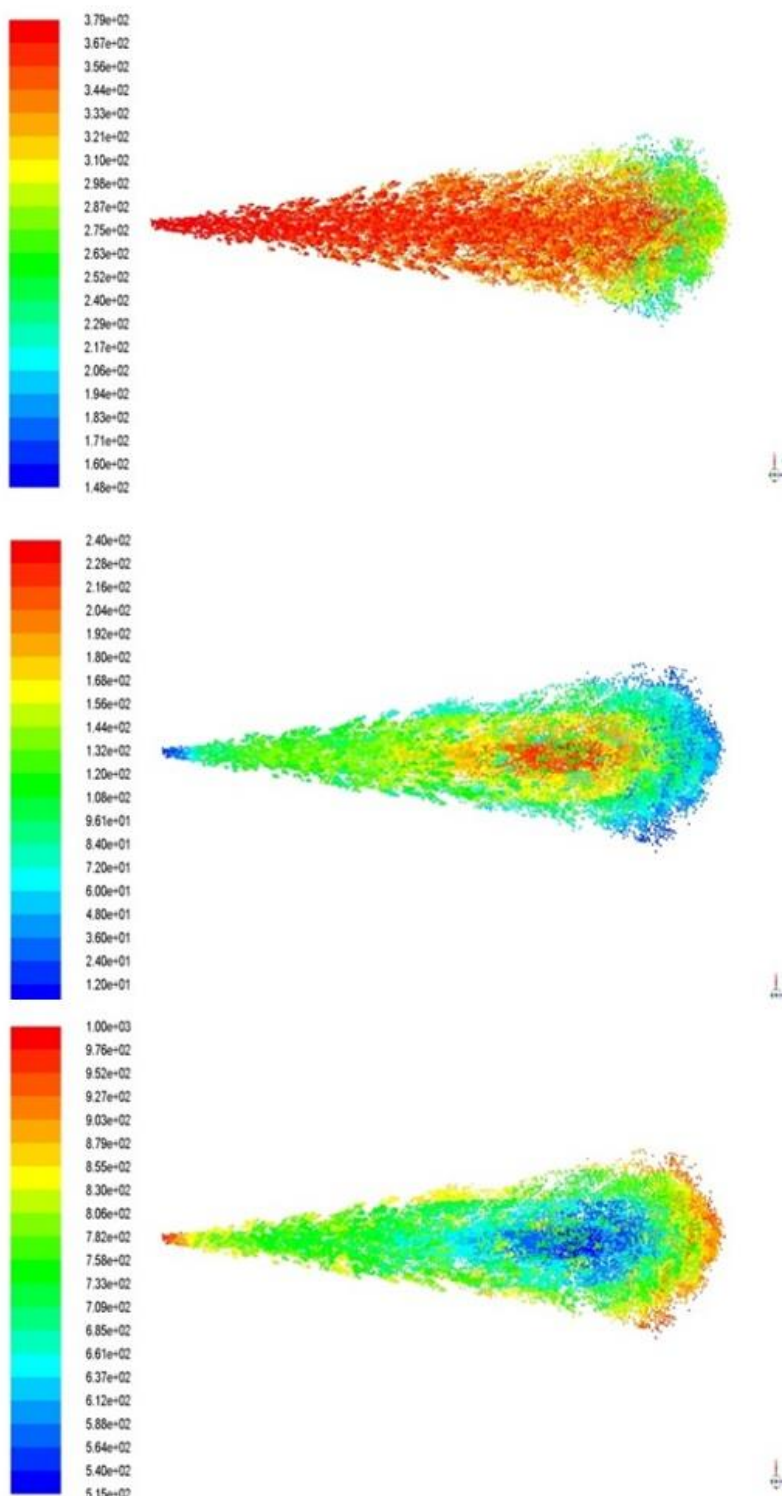

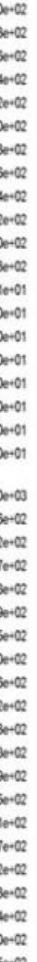

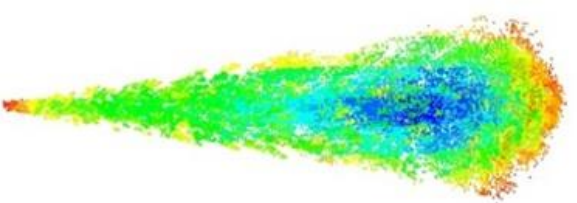

Fig. 6. Results of fuel injection analysis for injection pressure of $60 \mathrm{MPa}$ : from top to bottom: velocity of individual drops $\left[\mathrm{m} \cdot \mathrm{s}^{1}\right]$, average stream velocity $\left[\mathrm{m} \cdot \mathrm{s}^{1}\right]$, average temperature distribution in the stream $[\mathrm{K}]$ - pressure in the chamber $0.1 \mathrm{MPa}$. 

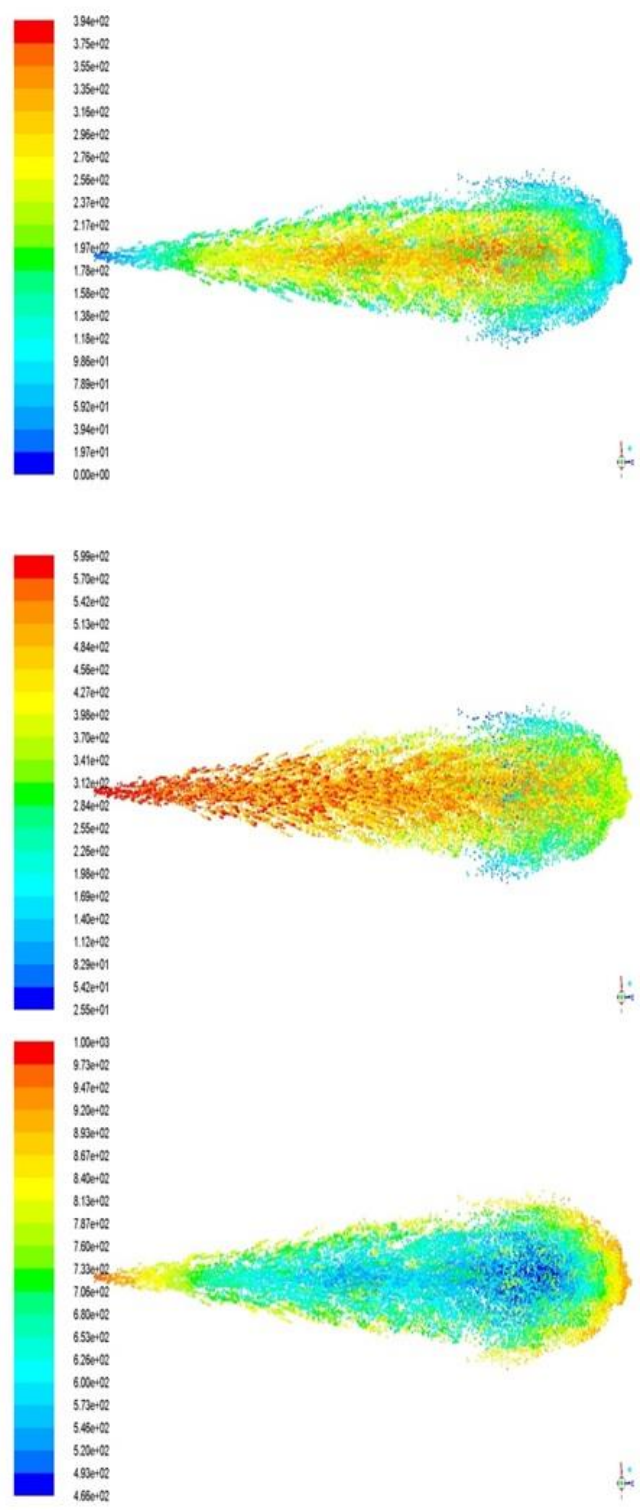

Fig. 7. Results of fuel injection analysis for injection pressure of $150 \mathrm{MPa}$ : from top to bottom: velocity of individual drops $\left[\mathrm{m} \cdot \mathrm{s}^{1}\right]$, average stream velocity $\left[\mathrm{m} \cdot \mathrm{s}^{1}\right]$, average temperature distribution in the stream $[\mathrm{K}]$ - pressure in the chamber $0.1 \mathrm{MPa}$.

The comparison of fuel injection results for $60 \mathrm{MPa}$ and $150 \mathrm{MPa}$ (Fig. 6 and Fig. 7), at a pressure value of 0.1 $\mathrm{MPa}$, exhibits that the velocity of the drops, at higher pressures, dissipates faster and the shape of the stream is more elongated. The average velocity of the stream in the first examined case (Fig. 2) is more centred and oscillates around $2.40^{\mathrm{e}+02} \mathrm{~m} \cdot \mathrm{s}^{-1}$, while at $150 \mathrm{MPa}$, the values are more scattered over the entire stream space and reach approx. $3.75-3.94^{\mathrm{e}-02} \mathrm{~m} \cdot \mathrm{s}^{-1}$. The average temperature distribution is similar but the values remain in the range of $1-5.15^{\mathrm{e}+02} \mathrm{~K}$ for the injection pressure of $60 \mathrm{MPa}$ and $1-4.66^{\mathrm{e}+02} \mathrm{~K}$ for the pressure of $150 \mathrm{MPa}$. This is due to the fact that at higher pressure the fuel combustion time and air flat flame is much shorter, the exhaust gases coming out are already cooler.

Afterwards, the same indicators were analysed at the changed pressure in the combustion chamber (0.15 MPa).
The dependencies in this case are similar, with the velocities of individual drops of $1.41-3.74^{\mathrm{e}+02} \mathrm{~m} \cdot \mathrm{s}^{-1}$ for the pressure of $60 \mathrm{MPa}$ (Fig. 8) and $2.49^{\mathrm{e}+01}-5.96^{\mathrm{e}+02} \mathrm{~m} \cdot \mathrm{s}^{-1}$ for the pressure of $150 \mathrm{MPa}$ (Fig. 9). The average velocity of the stream reaches lower maximum values for the lower set pressure $\left(0-2.38^{\mathrm{e}+02} \mathrm{~m} \cdot \mathrm{s}^{1}\right.$ compared to the range of $0-4.15^{\mathrm{e}+02} \mathrm{~m} \cdot \mathrm{s}^{1}$ for the pressure of $\left.150 \mathrm{MPa}\right)$. The distribution of temperature in the stream is similar both in visual and computational terms. For lower pressure (60 $\mathrm{MPa})$, the temperatures were within the range of $1^{\mathrm{e}+03}-$ $5.27^{\mathrm{e}+02} \mathrm{~K}$, while for higher pressure $(150 \mathrm{MPa})$ within the range of $1^{\mathrm{e}+03}-4.59^{\mathrm{e}+02} \mathrm{~K}$.

The laboratory tests using high-speed cameras showed that the shape of the fuel stream depended, inter alia, on the injection pressure. If compared to the obtained simulation results, similarity can be clearly seen.

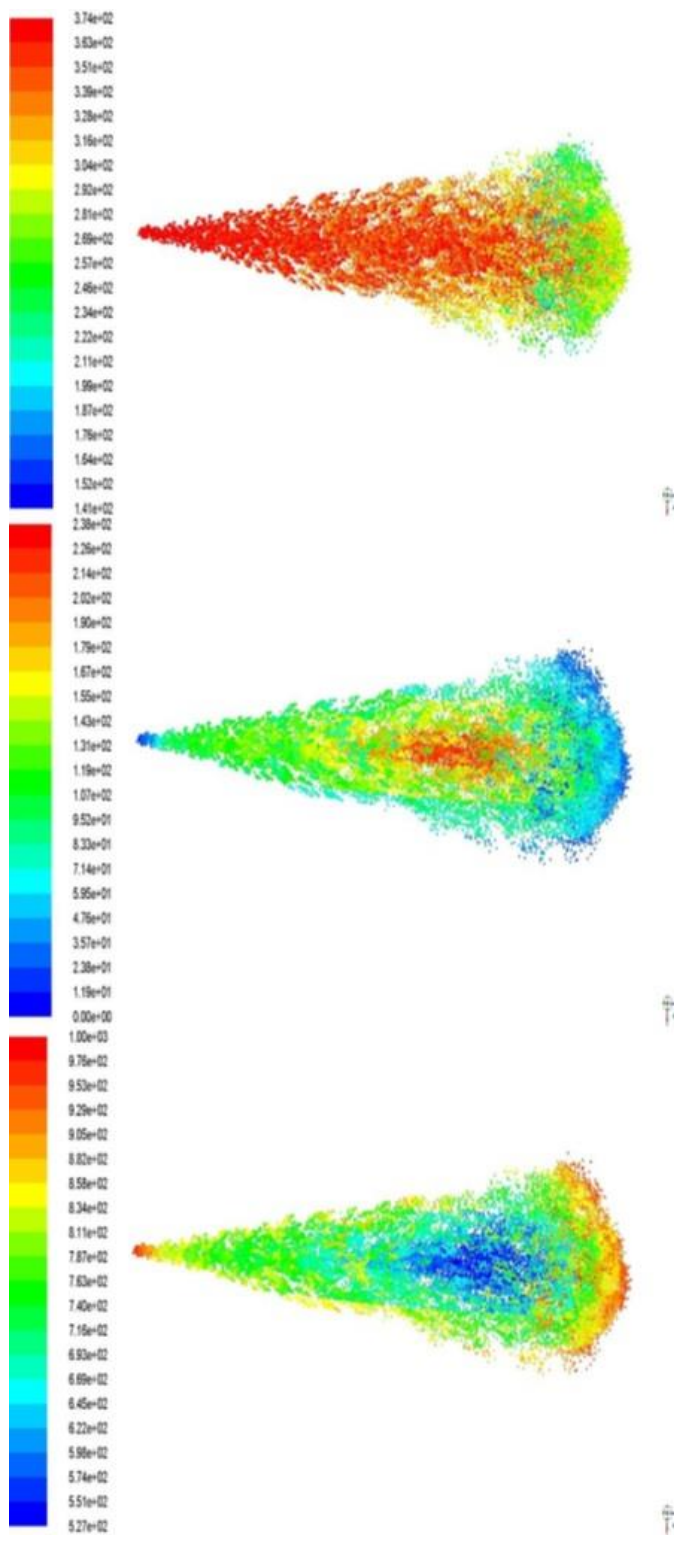

Fig. 8. Results of fuel injection analysis for injection pressure of $60 \mathrm{MPa}$ : from top to bottom: velocity of individual drops $\left[\mathrm{m} \cdot \mathrm{s}^{1}\right]$, average stream velocity $\left[\mathrm{m} \cdot \mathrm{s}^{1}\right]$, average temperature distribution in the stream $[\mathrm{K}]$ - pressure in the chamber $0.15 \mathrm{MPa}$. 
Based on the CFD data, it can be stated that the highest velocity of the stream is at its core. This is due to the highest concentration of energy, which is dispersed at a later stage of the process. Differences in the shape of the injection result from additional parameters, not included in the analysis, such as: vibration, cavitation disorders, contamination of fuel and the injector head.
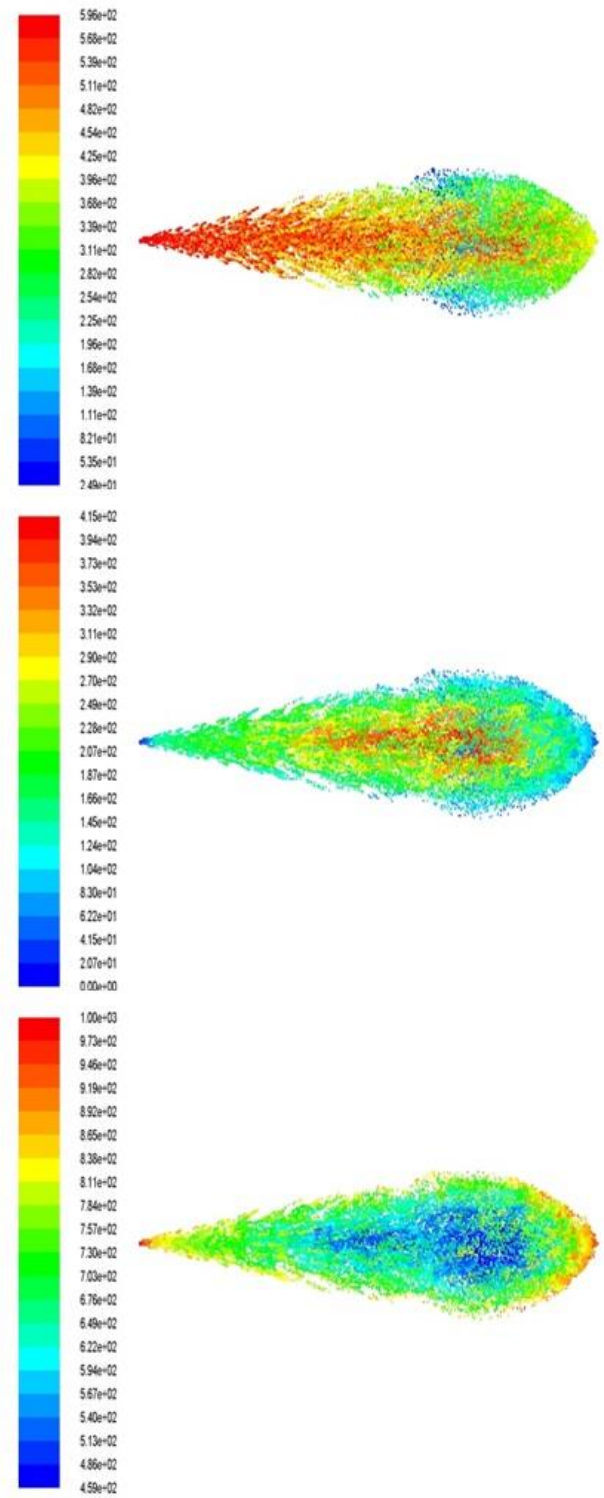

Fig. 9. Results of fuel injection analysis for injection pressure of $150 \mathrm{MPa}$ : from top to bottom: velocity of individual drops $\left[\mathrm{m} \cdot \mathrm{s}^{1}\right]$, average stream velocity $\left[\mathrm{m} \cdot \mathrm{s}^{1}\right]$, average temperature distribution in the stream $[\mathrm{K}]$. - pressure in the chamber $0.15 \mathrm{MPa}$

\section{Summary}

Based on the study, it can be concluded that:

1. The boundary conditions have been selected so as to best match the conditions of the experimental model. The simulation was carried out for the static conditions of the experiment, i.e. not accounting for the movement of the piston or dynamic changes in pressure and temperature in the combustion chamber.
2. Injection parameters were selected based on experimental data in order to best reflect the results of the experiment.

3. Differences in test results and simulations may be attributed to: grid limitations (the number of elements has been limited to 500,000), accuracy of the calculation models used, simplifications and limitations of computational capabilities.

4. As the injection velocity increases, the diameter of drops decreases. This is due to the increase in the flow turbulence and the instability of all drops.

5. The highest velocity values are found at the injection core. A large concentration of the fuel fraction moves along with the direction of injection, dissipating its energy in the form of disintegrated smaller drops.

6. The largest flow output is located in the stream axis, which lowers the temperature of the core in relation to the temperature in the combustion chamber as it moves along. This increases the time needed to heat up the drops, thus prolonging the time of their liquid state.

7. Numerical simulations are helpful in determining the work parameters of actual research objects, without the need to resolve to a test set-up. Unrestrained modifications in the simulation parameters enable shaping technical parameters of devices and their effect on a particular model.

\section{References}

1. C. Tolga, K. Saeed, A. Yusuf, Environ Impact Assess Rev. 64 (2017)

2. P. Weldon, P. Morrissey, M. O'Mahony, Sustain Cities Soc. 39 (2018)

3. J. Haller, T. Link, Int J Hydrogen Energ. 42, 44 (2017)

4. P. Singh, S.K. Tiwari, R. Singh, N. Kumar, Renew Sust Energ Rev 79 (2017)

5. M. Klimkieiwcz, Zastosowanie surowego oleju rzepakowego jako paliwa do silników wysokoprężnych ciągników i pojazdów rolnicznych. Raport $\mathrm{z}$ realizacji projektu rozwojwego $\mathrm{Nr}$ R1003703, SGGW, Warszawa

6. C. Bae, J. Kim, Proc Combust Inst 36, 6 (2017)

7. Y. Bicer, I. Dincer, Resour Conserv Recy 132 (2018)

8. P. Geng, E. Cao, Q. Tan, L. Wei, Renew Sust Energ Rev 71 (2017)

9. L. Duan, S. Yuan, L. Hu, W. Yang, J. Yu, X. Xia, Int. J. Heat Mass Transfer 93 (2016)

10. E. Frosina, A. Senatore, D. Buono, M.U. Manganelli, M. Olivetti, Energy Procedia 45 (2014)

11. H. Taghavifar, S. Khalilarya, S. Jafarmadar, Energy Convers Manag. 85 (2014)

12. A. Ravichandran, K. Rajan, M.R. Narayanan, K.S. Kumar, Int J Chem Tech Res 9 (2016)

13. S.T. Kumaravel, A. Murugesan, A. Kumaravel, Renew Sustain Energy Rev 60 (2016) 
14. N. Panneerselvam, A. Murugesan, C. Vijayakumar, A. Kumaravel, D. Subramaniam, A. Avinash, Renew Sustain Energy Rev 50 (2015)

15. A. Datta, B.K. Mandal, J Mech Sci Technol 30, 4 (2016)

16. N. Kumar, S.R. Chauhan, International Journal of Ambient Energy 37, 2 (2016)

17. P. Singh, Varun, S.R. Chauhan, J Mech Sci Technol 31, 4 (2017)

18. A. Babajimopoulos, D.N. Assanis, D.L. Flowers, S.M. Aceves, Hessel R.P., 15 ${ }^{\text {th }}$ International Multidimensional Engine Modeling User's Group Meeting, Detroit, MI, April 2005

19. K.V. Puduppakkam, L. Liang, C.V. Naik, E. Meeks, S.L. Kokjohn, R.D. Reitz, SAE Int. J. Engines. 4 (2011)

20. R.K. Maurya, P. Mishra, Fuel 2010 (2017)

21. I. Taritas, D. Kozarac, M. Sjeric, M. Aznar Sierra, SAE Int. J. Engines 10, 2 (2017)
22. L. Eder, C. Kiesling, P. Priesching, G. Pirker, SAE Tech. Pap. (2017)

23. Y. Varol, H.F. Oztop, M. Firat, A. Koca, Int Commun Heat Mass 37, 9 (2010)

24. J. Silva, J. Teixeira, S. Teixeira, S. Preziati, J. Cassiano, Energy Procedia 120 (2017)

25. M. Szubel, M. Papka, M. Filipowicz, Journal of Civil Engineering, Environment and Architecture 64, 4/I (2017)

26. M. Klimkiewicz, K. Błaszczuk, R. Mruk, K. Tucki, Agricultural Engineering 2, 143 (2013)

27. W. Tutak, Modelowanie Inżynierskie 49 (2013)

28. Z. Kosma, B. Piechnik, R. Kalbarczyk, Modelowanie Inżynierskie 48 (2013)

29. P. Paliszewski, I. Szczygieł, Postępy Nauki i Techniki 15 (2012)

30. D. Stępniak, Mechanik 7 (2015)

31. ANSYS Inc. ANSYS Fluent Theory Guide Release 14.0. November 2011 